\title{
Respiration of the belowground parts of vascular plants: its contribution to total soil respiration on a successional glacier foreland in Ny-Ålesund, Svalbard
}

\author{
T. NAKATSUBO, Y. BEKKU, A. KUME and H. KOIZUMI
}

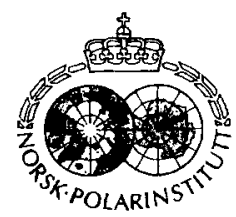

Nakatsubo, T., Bekku, Y., Kume, A. \& Koizumi, H. 1998: Respiration of the belowground parts of vascular plants: its contribution to total soil respiration on a successional glacier foreland in Ny-Ålesund, Svalbard. Polar Research 17(1), 53-59.

As a part of the study on soil carbon flow in a deglaciated area in Ny-Alesund, Svalbard $\left(79^{\circ} \mathrm{N}\right)$, we estimated the contribution of the belowground respiration of vascular plants to total soil respiration in August 1996. Four study sites were set up along a primary successional series, ranging from newly deglaciated moraine to older moraine with well-developed vegetation cover. Respiratory activity of the belowground parts (roots + belowground stems) of three dominant species, Salix polaris, Saxifraga oppositifolia and Luzula confusa, was determined under laboratory conditions. The respiratory activity and the $Q_{10}$ value of the respiration were higher in $S$. polaris than in the other two species. Total soil respiration rates measured in the field varied widely. The areas with dense vegetation cover tended to show high respiration rates. Belowground respiration of vascular plants was estimated based on the respiratory activity and biomass of the belowground parts at each study site. The contribution to the belowground respiration to total soil respiration was negligible in the early stages of succession. On the other hand, the respiration of the belowground parts contributed to a significant proportion $(\sim 29 \%)$ of the total soil respiration in the latter stages of succession.

T. Nakatsubo, Department of Environunental Studies, Faculty of Integrated Arts and Sciences, Hiroshima University, Kagamiyama 1-7-1, Higashi-Hiroshima, 739-8521 Japan; Y. Bekku, Department of Biology, National Institute of Polar Research, 9-10, Kaga-1, Itabashi, Tokyo, 173-8515 Japan; A. Kume, The Center for Forest Decline Studies, Faculty of Integrated Arts and Sciences, Hiroshima University, Kagamiyama 1. 7-1, Higashi-Hiroshima, 739-8521 Japan; H. Koizumi, Institute for Basin Ecosystem Studies, Gifu University, Gifu, 501-1112 Japan.

\section{Introduction}

Current global warming predictions indicate that warming will be more pronounced at high latitudes in the Northern Hemisphere (IPCC 1996). Northern ecosystems (arctic, boreal forests and northern bogs) are particularly sensitive to climatic change due to the large soil carbon pool and the predominance of permafrost (Oechel \& Vourlitis 1994). Elevated temperature may increase the decomposition rate by stimulating soil microbial activity and by increasing soil active layer. Although, a number of studies recently have been carried out to predict the impact of climate change on the soil carbon flow in northern ecosystems (cf. Oechel \& Vourlitis 1994), quantitative data of the soil carbon flow, especially for high arctic regions, is still limited.

In many of the studies on soil carbon flow, soil respiration has been used as an indicator of soil microbial activity and decomposition. However, in systems dominated by vascular plants, respira- tion of the belowground parts may contribute to a significant proportion of soil respiration. It has been reported that root respiration accounts for between 23 and $90 \%$ of the total soil respiration in forest ecosystems (Nakane et al. 1983; Ewel et al. 1987; Tate et al. 1993; Thierron \& Laudelout 1996; Uchida et al. 1998), Belowground parts may compose more than $80 \%$ of the living biomass in tundra (Wielgolaski 1972). Billings et al. (1978) estimated that root and rhizome respiration contributed to 50 to $90 \%$ of the total soil respiration in an arctic meadow. Thus, in order to relate the soil respiration to the soil microbial activity, it is necessary to determine the contribution of the belowground parts to total soil respiration.

As a part of the soil carbon flow in different stages of primary succession in a deglaciated area in the high arctic zone, we aimed at estimating the contribution of the belowground parts of vascular plants to the total soil respiration. For this purpose, we measured (1) the respiration rates of 


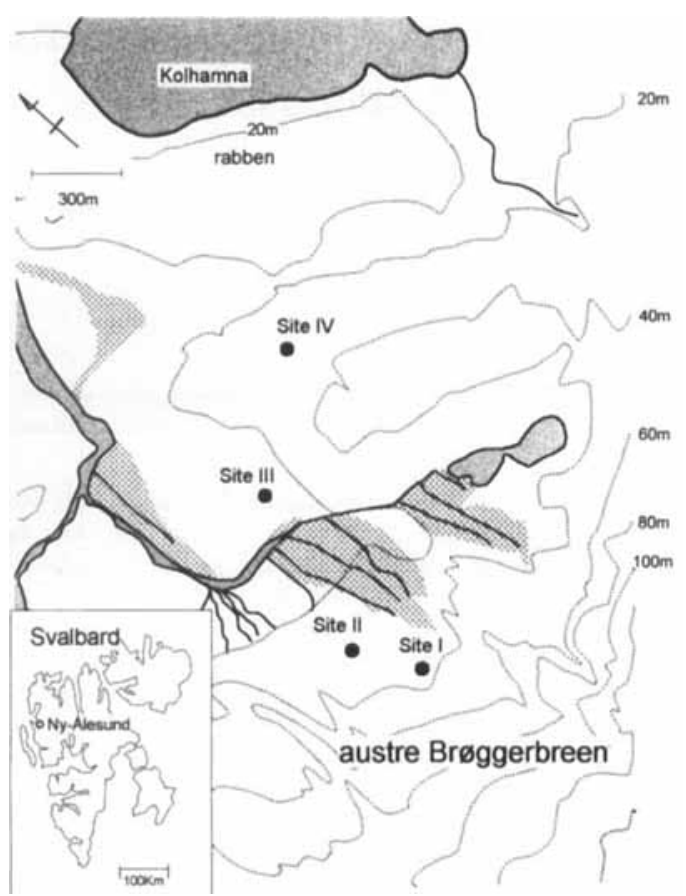

Fig. 1. Study sites in Ny-Ålesund, Svalbard.

belowground parts of dominant vascular plants, (2) the biomass of the belowground parts and (3) the total soil respiration rate in the field.

\section{Materials and methods}

\section{Study sites}

This study was carried out within the Japan-Norway cooperative study "Ecosystem Change at the Glacier-edge Areas in the Arctic". The glacier austre Brøggrebreen is located near Ny-Ålesund in the northwestern part of Spitsbergen, Svalbard $\left(79^{\circ} \mathrm{N}\right)$, Norway. In 1994 , four permanent plots (Sites I, II, III and IV) were set up along a primary successional series in the deglaciated area of austre Brøggrebreen. Some soil properties of these study sites are summarised in Table 1.

Site I was the youngest site situated on a newly deglaciated moraine. Only isolated small plants such as Saxifraga oppositifolia L. grew at this site. The coverage of vascular plants was very small $(<1 \%)$, but black crusts of cyanobacteria and several species of bryophytes partially covered the ground (cf. Minami et al. 1996).

At Site II, small patches of vascular plants such as Saxifraga oppositifolia, Poa alpina L. and Draba spp. were found, though the coverage of the plants was still low $(<10 \%)$.

Site III was characterised by a patterned ground composed of small polygons (Fig. 2). The diameter of each polygon ranged from about 50 to $100 \mathrm{~cm}$. A mixed community of bryophytes and vascular plants $(\mathrm{Mv})$ covered the marginal part of the polygons, whereas the central part consisted of almost bare ground $(\mathrm{Bg})$. Black crust of cyanobacteria and lichens $(\mathrm{Cl})$ covered the area between $\mathrm{Mv}$ and $\mathrm{Bg}$. The percentage cover of $\mathrm{Mv}, \mathrm{Cl}$ and $\mathrm{Bg}$ was 53,30 and $17 \%$, respectively.

Site IV was similar to Site III except that the black crust entirely covered the central part of the polygons. Relative coverage of $\mathrm{Mv}$ and $\mathrm{Cl}$ was 45 and $55 \%$, respectively.

\section{Belowground respiration}

The respiratory activity of the belowground parts (roots + belowground stems) of the dominant three species, Salix polaris Walenb., Saxifraga oppositifolia and Luzula confusa (Hartm.) Lindeb., was determined in the laboratory at $\mathrm{Ny}$ Allesund. S. polaris is reported to be an ectomycorrhizal species while the other two species are non-mycorrhizal in Spitsbergen (Väre et al. 1992). Unless otherwise noted, these species will henceforth be referred to by their generic names. The plants were dug out with adhering soil and brought to the laboratory. After they were washed carefully to remove soil particles, the aboveground part was cut off. The sample, about 1-6g in dry weight, was placed on a filter paper in a petri dish $(\varnothing=7 \mathrm{~cm})$. The sample and the filter paper were wetted with water occasionally to prevent desiccation. Five replicate samples of each species were stored at temperatures of $6 \pm 3^{\circ} \mathrm{C}$ until the respiration measurement. This temperature condition was similar to the soil temperature in the field.

The respiration rate of the belowground parts was measured using an open-flow gas exchange system with an infrared gas analyzer (IRGA) (LI6252, LI-COR, NE, USA). A detailed description of this system appeared in Bekku et al. (1997). The IRGA was calibrated using a standard gas containing $431 \mathrm{ppm} \mathrm{CO}_{2}$ (GL Sciences, Tokyo, Japan) and $\mathrm{CO}_{2}$-free air prior to the measurement. 
Table 1. Some soil properties of the study sites.

\begin{tabular}{lcccccc}
\hline Site & $\begin{array}{c}\text { Thickness of } \\
\text { O horizon } \\
(\mathrm{cm})\end{array}$ & $\mathrm{C} \% \%^{*}$ & $\mathrm{~N} \% \%^{*}$ & $\mathrm{C} / \mathbf{N}^{*}$ & $\begin{array}{c}\mathrm{pH}^{*} \\
\left(\mathbf{H}_{2} \mathbf{O}\right)\end{array}$ & $\begin{array}{c}\text { Soil water } \\
\text { content** } \\
(\%)\end{array}$ \\
\hline I & 0 & 1.6 & 0.02 & 80 & 6.7 & 11 \\
II & 0 & 1.8 & 0.05 & 36 & 6.7 & 21 \\
III & $0-3$ & 7.0 & 0.37 & 19 & 5.8 & 92 \\
IV & $1-3$ & 14.5 & 0.83 & 17 & 5.7 & 130 \\
\hline
\end{tabular}

* Average of $0-5 \mathrm{~cm}$ layer.

** (Fresh weight-Dry weight)/Dry weight: determined on 27-30 July 1996.

The petri dish with the sample was placed in a cylindrical chamber $(\varnothing=9 \mathrm{~cm}, \mathrm{~h}=3.5 \mathrm{~cm})$ connected with the system. Ambient air containing $347-350 \mathrm{ppm} \mathrm{CO}_{2}$ was flowed into the system at the rate of $0.51 \mathrm{~min}^{-1}$. During the measurement of the respiration, the chamber was placed in a portable refrigerator or a water bath to control the temperature conditions. The temperature in the chamber was monitored using a copper-constan$\tan$ thermocouple. Unless otherwise noted, the temperature in the chamber was controlled at $8 \pm 0.5^{\circ} \mathrm{C}$.

In previous studies (e.g. Tate et al. 1993), it was reported that plant roots showed a high respiration rate immediately after the sampling. Therefore, we monitored the respiration rate at $1,4,7$ and 9 days following the sample collection.

Temperature dependence of the respiration was also examined by changing the temperature from 2 to $12^{\circ} \mathrm{C}$ at every $3-4^{\circ} \mathrm{C}$ interval. About $4-6$ hours were required to obtain the temperaturerespiration curve of each sample. In some experiments, the temperature was again decreased from 12 to $2^{\circ} \mathrm{C}$ to determine whether a hysteresis occurred or not. Hysteresis was not observed in any of the cases.

After the respiration measurements, the samples were freeze-dried to calculate the dry weight.

\section{Total soil respiration in the field}

Five areas representing typical vegetation cover at each site were selected for the measurements of total soil respiration. The aboveground parts of vascular plants and the green bryophyte layer were cut off. Two or three days prior to the measurement, a cylindrical soil collar $(\varnothing=10.5 \mathrm{~cm})$ was carefully driven into the soil at a depth of $1 \mathrm{~cm}$ in each area (cf. Fig. 2). The soil respiration chamber (LI-6000-09, LI-COR, NE, USA) was placed on the soil collar and the soil respiration rate was measured using a portable infrared gas analyzer (LI-6200, LI-COR, NE, USA). A detailed description of this system is given in Rochette et al. (1991, 1992).

In the previous year of this study (1995), seasonal variations of soil respiration rate were studied at the same sites as those in this study. However, no clear seasonal change of the rate was observed from early July to mid August (Fig. 3). In this study, therefore, the measurement of soil respiration was carried out in early August ( 3 August 1996).

After the measurement of soil respiration, the belowground parts within the soil collar were collected. They were separated into species and were freeze-dried to obtain the dry weight.

\section{Results and discussion}

\section{Belowground respiration rate differences}

Fig. 4 shows the changes in the respiratory activity of the belowground parts in Salix, Saxifraga and Luzula following sample collection. The respiration rate of Salix was highest immediately after sample collection, possibly due to injury by excision and disturbance. It then decreased rapidly and no significant change was observed 4 days after sample collection. Such changes were not apparent in the respiratory activity of Saxifraga and Luzula.

In this measurement, the aboveground parts were cut from the belowground parts, so no assimilates and no nutrients reached the belowground parts. Nevertheless, no apparent decline in 


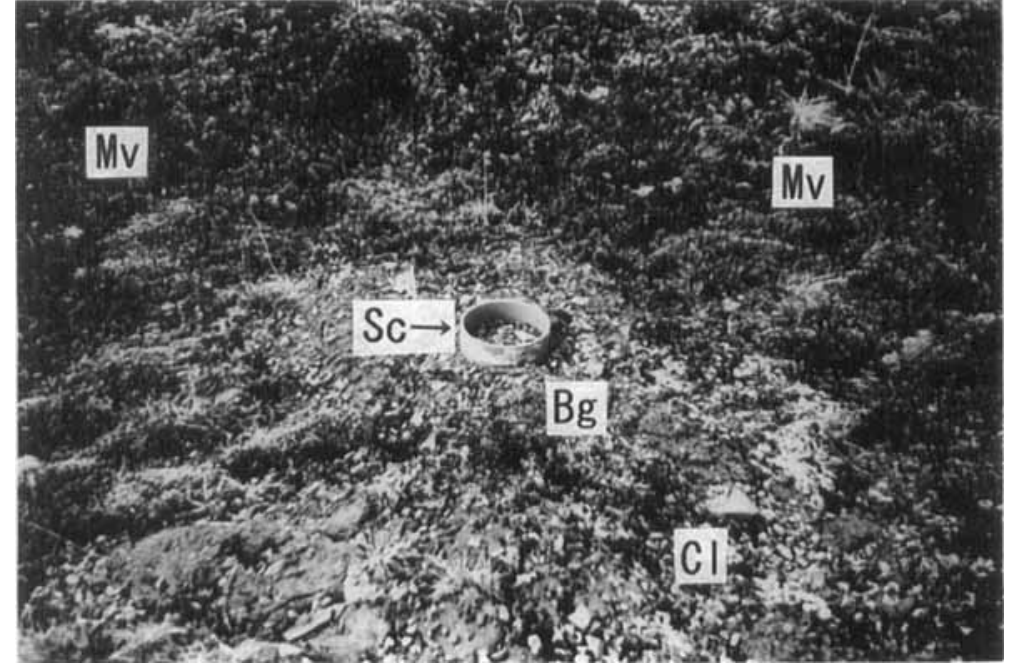

Fig. 2. Study site (Site III) on the old moraine in $\mathrm{Ny}$-Ålesund, Svalbard. $\mathrm{Bg}=$ bare ground, $\mathrm{Cl}=$ crust of cyanobacteria and lichens, $\mathrm{Mv}=$ mixed community of bryophytes and vascular plants, $\mathrm{Sc}=$ soil collar used for soil respiration measurements $(\phi=10.5 \mathrm{~cm})$. the respiration rate was observed at least from 4 to 9 days after sample collection. Moreover, the materials used in the measurements regenerated new organs (see below). These results agree with the previous reports that plant roots excised from main stem could survive and maintain their respiratory activity for more than 10 days (e.g. Tate et al. 1993; Uchida et al. 1998).

The respiratory activity in the stable phase (4-9 days) of Salix and Saxifraga was within the range of root respiration in arctic plants reported by Earnshaw (1981), though Skre (1975) reported much higher values for some tundra plants. However, in this study, the respiration rates differed widely between the species; the average respiration rate was much higher in Salix than in Saxifraga and Luzula (Table 2). This higher respiration rate in Salix may be partly due to its well-developed belowground stem. The belowground stem of Salix appeared to have a high activity; excised belowground stem of Salix could regenerate new leaves and roots within a week in the laboratory. On the other hand, regeneration of new organs from the belowground parts was much slower in the other species.

The $Q_{10}$ values of the respiration obtained in this study (Table 2) were similar to those of many arctic plants so far reported (Skre 1975; Billings et al. 1978; Earnshaw 1981). However, as in the case of the respiration activity, the $\mathrm{Q}_{10}$ values differed significantly between the species in this study;
Salix showed the largest $\mathrm{Q}_{10}$ value which reflects its high sensitivity to temperature.

\section{Belowground respiration and soil respiration}

The amount of biomass of the belowground parts of vascular plants was almost negligible in the earlier stages of succession (Sites I and II) (Table 3 ). There were several species of vascular plants such as Saxifraga oppositifolia, Luzula confusa, Equisetum variegatum Schleich. and Oxyria digyna (L.) Hill. in the latter stages of the succession (Sites III and IV). However, in most of the areas studied, Salix polaris predominated in the belowground biomass (Table 3 ).

Total soil respiration rates in the earlier stages of succession (Sites I and II) were usually lower than those in the latter stages (Sites III and IV). However, soil respiration rates comparable to those of the latter stages were detected in some areas (e.g. No. 7 at site II) (Table 3).

Average rate of total soil respiration was highest at Site III though the rate varied widely among the five areas studied. This large variation in the soil respiration rates was probably due to the heterogeneity of this site; the lowest rate (12.8 $\mathrm{mgCO}_{2} \mathrm{~m}^{-2} \mathrm{~h}^{-1}$ ) was observed in the central part of the polygon (No. 11), while high rates were restricted to the marginal parts of the polygons (Nos. 13 and 15) with a well-developed vegetation cover. Soil respiration rates in the areas 


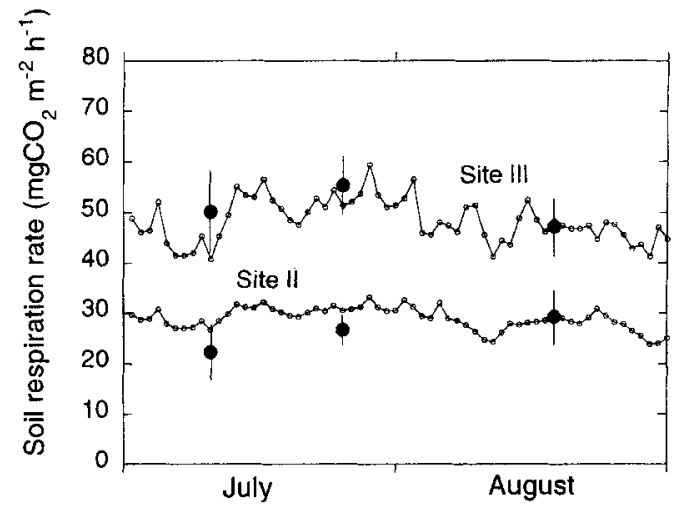

Fig. 3. Seasonal variations of soil respiration rate (SR) at Sites Il and III in July and August 1995. Soil respiration rates were measured at the same study sites in the same manner as those in this study. Solid circles indicate the measured values (mean $\pm \mathrm{SD} ; \mathrm{n}=5$ ). Open symbols show the rates estimated by the regression curves between $\mathrm{SR}$ and air temperature (AT) or soil temperature (ST). Site II: $\mathrm{SR}=25.4 \exp (0.0372 * \mathrm{AT})$; Site III: $S R=37.2 \exp (0.0624 * S T)$.

covered with a black crust $(\mathrm{Cl})$ gave intermediate values (Nos. 12 and 14).

At Site IV, areas Nos. 17 and 19 corresponded to the mixed community of bryophytes and vascular plants $(\mathrm{Mv})$, and areas Nos. 16, 18 and 20 to the areas covered with a black crust $(\mathrm{Cl})$. However, there was no distinct difference in the soil respiration rate between the two vegetation types $(\mathrm{Mv}$ and $\mathrm{Cl})$. The range of total soil respiration was smaller at Site IV (33.6-47.4 mgCO $\mathrm{m}^{-2} \mathrm{~h}^{-1}$ ) than at Site III (12.8-96.4 $\mathrm{mgCO}_{2} \mathrm{~m}^{-2} \mathrm{~h}^{-1}$ ).

Because of the wide variation within each site, the difference in soil respiration rate between sites was not significant (ANOVA, P > 0.05). On the other hand, the effect of vegetation types on soil respiration rate was highly significant (ANOVA, $\mathrm{P}<0.001$ ).

The total soil respiration rates obtained in these study sites were much lower than those reported for Alaskan arctic tundra (Billings et al. 1978; Oberbauer et al. 1986). This is possibly because of the thin $\mathrm{O}$ horizon in these study sites (Table 1 ).

The respiration rates of the belowground parts of the vascular plants in the field were estimated based on the amount of biomass (Table 3) and respiration rate per dry weight (Table 2). The respiration rates were corrected for the field temperature using the $\mathrm{Q}_{10}$ value (Table 2). Since
Table 2. Respiration rates of the belowground parts (roots + belowground stems) and $\mathrm{Q}_{10}$ values of the respiration in the arctic plants.

\begin{tabular}{lcc}
\hline & $\begin{array}{c}\text { Respiration rate at } \\
8^{\circ} \mathrm{C}^{*} \\
\left(\mathrm{mgCO}_{2} \mathrm{~g}^{-1} \mathrm{~h}^{-1}\right)\end{array}$ & $\begin{array}{c}\mathrm{Q}_{10}^{* *} \\
\left(5-12^{*} \mathrm{C}\right)\end{array}$ \\
\hline $\begin{array}{l}\text { Species } \\
\begin{array}{c}\text { Saxifraga } \\
\text { oppositifolia }\end{array}\end{array}$ & $0.175(0.014)^{\mathrm{a}}$ & $2.40(0.05)^{\mathrm{a}}$ \\
Luzula confusa & $0.126(0.039)^{\mathrm{ab}}$ & $1.95(0.25)^{\mathrm{ab}}$ \\
\hline
\end{tabular}

* Values indicate means of five samples with $\mathrm{SE}$ in parentheses.

** Values indicate means of three samples with $\mathrm{SE}$ in parentheses.

Means followed by the same letter within a column are not significantly different (Scheffe's test, $\mathrm{P}>0.05$ ).

the amount of belowground biomass of each species other than Salix was small, the mean value of the respiration rates of Saxifraga and Luzula $\left(0.091 \mathrm{mgCO}_{2} \mathrm{~g}^{-1} \mathrm{~h}^{-1}\right)$ was used to calculate the rates for the other species. For these species, mean $\mathrm{Q}_{10}$ value of the two species (1.8) was also used to estimate the respiration rate at the field temperature.

The estimated belowground respiration rate was almost negligible in the earlier stages of succession as in the case of the amount of biomass of the belowground parts (Table 3 ). In the latter stages of succession, estimated respiration rates varied widely among the five areas at each study site. At Site III, the respiration rates of the belowground parts showed a close correlation with the vegetation cover; high rates were restricted to areas with a well-developed vegetation cover (Nos. 13 and 15). The correlation between the respiration rate and the vegetation cover was less distinct at Site IV.

It appeared that the large site-to-site variation in the amount of biomass and respiration rate was inevitable in such heterogeneous habitats as those at the study sites. However, since the sampling areas were selected with consideration for the relative abundance of the vegetation types, the mean value of the respiration rates in the five areas could be regarded as the representative value for each site. The mean values of the percentage contribution of the belowground parts to total soil respiration at Sites I, II, III and IV were $0,0.1,29.4$ and $23.0 \%$, respectively. The values in the latter stages of succession (Sites III and IV) were comparable to those reported for 
Table 3. Biomass of the belowground parts, total soil respiration $\left(\mathbf{R}_{\text {1otal }}\right)$ and estimated belowground respiration of vascular plants $\left(R_{\text {root }}\right)$ at the four study sites (3 Aug. 1996).

\begin{tabular}{|c|c|c|c|c|c|c|c|c|}
\hline \multirow[b]{2}{*}{ Site } & \multirow[b]{2}{*}{ No. } & \multirow{2}{*}{$\begin{array}{l}\text { Vegetation* } \\
\text { cover }\end{array}$} & \multirow{2}{*}{$\begin{array}{c}\text { Soil** } \\
\text { temp. } \\
\left({ }^{\circ} \mathrm{C}\right)\end{array}$} & \multicolumn{2}{|c|}{$\begin{array}{l}\text { Biomass } \\
\left(\mathrm{g} \mathrm{m}^{-2}\right)\end{array}$} & \multicolumn{2}{|c|}{$\begin{array}{c}\text { Respiration } \\
\left(\mathrm{mgCO}_{2} \mathrm{~m}^{-2} \mathrm{~h}^{-1}\right)\end{array}$} & \multirow{2}{*}{$\begin{array}{c}\mathrm{R}_{\text {root }} / \mathrm{R}_{\text {total }} \times 100 \\
(\%)\end{array}$} \\
\hline & & & & Salix & others & $\mathrm{R}_{\text {total }}$ & $\mathbf{R}_{\text {root }}$ & \\
\hline \multirow[t]{5}{*}{ I } & 1 & $\mathrm{Bg}$ & 9.3 & 0.0 & 0.0 & 8.3 & 0.0 & 0.0 \\
\hline & 2 & $\mathrm{Bg}$ & 9.7 & 0.0 & 0.0 & 19.5 & 0.0 & 0.0 \\
\hline & 3 & $\mathrm{Bg}$ & 9.4 & 0.0 & 0.0 & 18.1 & 0.0 & 0.0 \\
\hline & 4 & $\mathrm{Bg}$ & 10.1 & 0.0 & 0.0 & 31.6 & 0.0 & 0.0 \\
\hline & 5 & $\mathrm{Bg}$ & 11.1 & 0.0 & 0.0 & 0.0 & 0.0 & 0.0 \\
\hline \multirow[t]{5}{*}{ II } & 6 & $\mathrm{Bg}$ & 7.2 & 0.0 & 0.0 & 32.6 & 0.0 & 0.0 \\
\hline & 7 & $\mathrm{Bg}$ & 8.2 & 0.0 & 2.8 & 41.9 & 0.3 & 0.6 \\
\hline & 8 & $\mathrm{Bg}$ & 8.6 & 0.0 & 0.0 & 21.3 & 0.0 & 0.0 \\
\hline & 9 & $\mathrm{Bg}$ & 8.1 & 0.0 & 0.0 & 7.6 & 0.0 & 0.0 \\
\hline & 10 & $\mathrm{Bg}$ & 8.5 & 0.0 & 0.0 & 20.6 & 0.0 & 0.0 \\
\hline \multirow[t]{5}{*}{ III } & 11 & $\mathrm{Bg}$ & 7.6 & 4.2 & 1.4 & 12.8 & 0.8 & 6.5 \\
\hline & 12 & $\mathrm{Cl}$ & 7.3 & 0.0 & 22.3 & 54.8 & 2.0 & 3.6 \\
\hline & 13 & $\mathrm{Mv}$ & 6.2 & 352.0 & 0.0 & 81.2 & 52.6 & 64.8 \\
\hline & 14 & $\mathrm{Cl}$ & 7.6 & 22.3 & 12.6 & 39.5 & 4.9 & 12.4 \\
\hline & 15 & $\mathrm{Mv}$ & 6.9 & 345.0 & 33.5 & 96.4 & 57.7 & 59.8 \\
\hline \multirow[t]{5}{*}{ IV } & 16 & $\mathrm{Cl}$ & 7.4 & 72.6 & 18.2 & 47.4 & 13.7 & 28.8 \\
\hline & 17 & Mv & 5.9 & 117.3 & 4.2 & 37.6 & 17.4 & 46.4 \\
\hline & 18 & $\mathrm{Cl}$ & 7.4 & 0.0 & 5.6 & 33.6 & 0.5 & 1.5 \\
\hline & 19 & $\mathrm{Mv}$ & 6.3 & 46.1 & 2.8 & 38.6 & 7.2 & 18.6 \\
\hline & 20 & $\mathrm{Cl}$ & 6.9 & 41.9 & 14.0 & 39.8 & 7.9 & 19.7 \\
\hline
\end{tabular}

* $\mathrm{Bg}$; bare ground, $\mathrm{Cl}$; crust of cyanobacteria and lichens, $\mathrm{Mv}$; mixed community of bryophytes and vascular plants.

** Soil temperature at $1 \mathrm{~cm}$ depth.

grassland ecosystems (Gupta \& Singh 1981; Buyanovsky et al. 1987).

The soil respiration rates and respiratory activity of the belowground parts may change

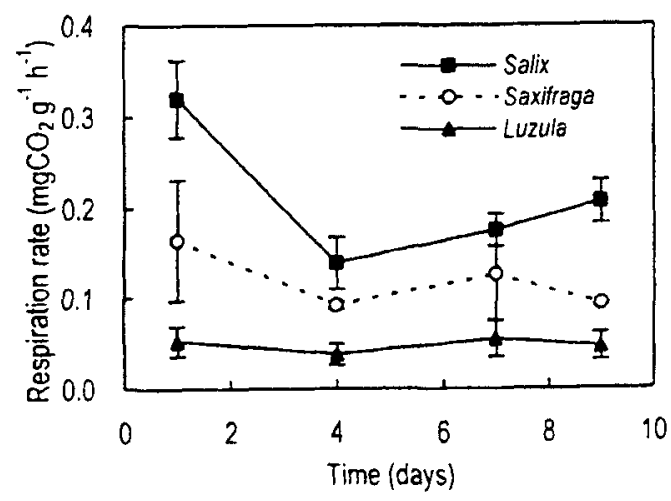

Fig. 4. Changes in the respiratory activity of the belowground parts of three arctic plants after sample collection. Temperature in the respiration chamber was controlled at $8 \pm 0.5^{\circ} \mathrm{C}$. Mean values of five samples are shown with $S E$. seasonally. However, the results obtained indicated that belowground respiration of vascular plants can contribute significantly to the soil carbon flow even in the high arctic zone, presumably due to the significant belowground carbon allocation in these plants.

Acknowledgements. - We thank the Norwegian Polar Institute and National Institute of Polar Research (NIPR) for field logistics and support. We also thank H. Kanda of NIPR and T. Masuzawa of Shizuoka University for their helpful advice and encouragement, and Y. Minami of Tamagawa University for providing us the unpublished soil data. This study was supported by a Grant-in Aid for Scientific Research from the Ministry of Education, Science and Culture of Japan, No. 06044224.

\section{References}

Bekku, Y., Koizumi, H., Oikawa, T. \& Iwaki, H. 1997: Examination of four methods for measuring soil respiration. Applied Soil Ecol. 5, 247-254.

Billings, W. D., Peterson, K. M. \& Shaver, G. R. 1978: Growth, turnover, and respiration rates of roots and tillers in tundra 
graminoids. Pp. 415-434 in Tieszen, L. L. (ed.): Vegetation and Production Ecology of Alaskan Arctic Tundra. SpringerVerlag, New York.

Buyanovsky, G. A., Kucera, C. L. \& Wagner, G. H. 1987: Comparative analysis of carbon dynamics in native and cultivated ecosystems. Ecol. 68, 2023-2031.

Earnshaw, M. J. 1981: Arrhenius plots of root respiration in some arctic plants. Arct. Alp. Res. 13, 425-430.

Ewel, K. C., Cropper, W. P. Jr. \& Gholz, H. L. 1987: Soil CO 2 evolution in Florida slash pine plantations. II. Importance of root respiration. Can. J. For. Res. 17, 330-333.

Gupta, S. R. \& Singh, J. S. 1981: Soil respiration in a tropical grassland. Soil. Biol. Biochem. 13, 261-268.

IPCC 1996: Climate Change 1995 The Science of Climate Change. Cambridge University Press, Cambridge. 572pp.

Minami, Y., Kanda, H. \& Masuzawa, T. 1996: The relationship between distribution of bryophytes and soil conditions on deglaciated arctic terrain in Ny-Älesund. Proc. NIPR Symp. Polar Biol. 9, 307-312.

Nakane, K., Yamamoto, M. \& Tubota, H. 1983: Estimation of root respiration rate in a mature forest ecosystem. Jpn. $J$. Ecol. 33, 397-408.

Oberbauer, S. F., Oechel, W. C. \& Riechers, G. H. 1986: Soil respiration of Alaskan tundra at elevated atmospheric carbon dioxide concentrations. Plant and Soil 96, 145-148.

Oechel, W. C. \& Vourlitis, G. L. 1994: The effects of climate change on land-atmosphere feedbacks in arctic tundra regions. TREE 9, 324-329.
Rochette, P., Desjardins, R. L. \& Pattey, E. 1991: Spatial and temporal variability of soil respiration in agricultural fields. Can. J. Soil Sci. 71, 189-196.

Rochette, P., Gregorich, E. G. \& Desjardins, R. L. 1992: Comparison of static and dynamic closed chambers for measurement of soil respiration under field conditions. Can. J. Soil Sci. 72, 605-609.

Skre, O. 1975: $\mathrm{CO}_{2}$ exchange in Norwegian tundra plants studied by infrared gas analyzer technique. Pp. 168-183 in Wielgolaski, F. E. (ed.): Fennoscandian Tundra Ecosystems Part 1 Plants and Microorganisms. Springer-Verlag, Berlin. Tate, K. R., Ross, D. J., O'Brien, B. J. \& Kelliher, F. M. 1993: Carbon storage and turnover, and respiratory activity, in the litter and soil of an old-growth southern beech (Nothofagus) forest. Soil Biol. Biochem. 25, 1601-1612.

Thierron, V. \& Laudelout, H. 1996: Contribution of root respiration to total $\mathrm{CO}_{2}$ efflux from the soil of a deciduous forest. Can. J. For. Res. 26, 1142-1148.

Uchida, M., Nakatsubo, T., Horikoshi, T. \& Nakane, K. 1998 : Contribution of microorganisms to the carbon dynamics in black spruce (Picea mariana) forest soil in Canada. Ecol. Res. 13, 17-26.

Väre, H., Vestberg, M. \& Eurola, S. 1992: Mycorrhiza and root-associated fungi in Spitsbergen. Mycorrhiza 1, 93-104.

Wielgolaski, F. E. 1972: Vegetation types and plant biomass in tundra. Arct. Alp, Res. 4, 291-305. 